\title{
EL DESAFÍO DEL CINISMO ANTIGUO EN LA POLIS (S. IV-III A.C.): UNA VIDA DE ESFUERZO Y DE REACUÑACIÓN DE LOS VALORES
}

\author{
THE CHALLENGE OF ANCIENT CYNICISM \\ WITHIN THE GREEK CITY STATE (S. IV-III \\ BC): LIVING A LIFE OF TOIL AND RECOINING \\ CURRENT VALUES
}

\author{
Pedro Pablo Fuentes González ${ }^{1}$ \\ Facultad de Filosofía y Letras \\ Universidad de Granada
}

\begin{abstract}
Resumen: Hombres y mujeres de un tiempo de crisis, los primeros cínicos representaron un verdadero desafío para sus contemporáneos. Radicalmente opuestos a los modos de vida y de pensamiento imperantes, lejos de apartarse en un retiro indiferente, se mantuvieron conscientemente en el interior de la sociedad de su tiempo. Lo hicieron ante todo como el mejor modo de realizar el cinismo por ellos descubierto, a través del desaprendizaje y desembarazo de todo aquello que está en el origen de la esclavitud y desdicha reales del individuo, y como el mejor modo de confirmar las
\end{abstract}

\footnotetext{
${ }^{1}$ Departamento de Filología Griega y Filología Eslava, Campus universitario de Cartuja S/N, Facultad de Filosofía y Letras, Universidad de Granada, 18071, Granada. E-mail: fuentes@ ugres. Profesor Titular de Filología Griega. Este artículo reelabora los contenidos principales de la ponencia presentada en el curso de la UNED El mundo de Alejandro, celebrado los días 6, 7 y 8 de julio de 2011 en Denia bajo la sabia y cordial dirección del profesor Quintín Racionero. A su memoria lo dedico, con todo mi agradecimiento por su confianza y generosidad.
} 
claves de la verdadera libertad y felicidad. En ese contexto hostil es donde, como atletas y soldados de la filosofía, se entrenaron y combatieron cotidiana y públicamente, con el objetivo de convertirse en seres autosuficientes, libres y felices. Antístenes, Diógenes, Crates, Metrocles y su hermana Hiparquia (esposa de Crates) representaron por excelencia ese lado más decididamente heroico y desafiante del cinismo antiguo. Poco después otros, como Menipo o Bion, prosiguieron este desafío en el mundo helenístico, aunque quizá en su caso se tradujo más en críticas y sátiras literarias que en un compromiso real de vida. Sin embargo, será sobre todo en época imperial cuando proliferará la figura del falso cínico vulgar, que ocultaba los vicios del parásito bajo la apariencia y la indumentaria del filósofo.

Palabras clave: Cinismo antiguo, Socratismo, Ética, Individualismo, Naturaleza, Sencillez, Autosuficiencia, Reacuñación de los valores, Ascesis, Aprendizaje, Voluntad, Impasibilidad, Libertad, Felicidad, Antístenes, Diógenes, Crates, Metrocles, Hiparquia, Menipo, Bion.

Aвstract: In an era of general crisis of the traditional city state, the first Cynics, both men and women, offered a challenge to their fellow countrymen. While despising in a radical way all the ways of life and currents of thought of their time, they refused to remain indifferent outside the city and chose to deliver their message through an active presence within the community. This involvement was for them the best and only way of getting rid of, and "unlearning" all the practices and values that could enslave someone and make him unhappy, and also of trying new paths to unconditional access to real freedom and happiness. To face the hostility of society and the hardness of life, they — as athletes and soldiers of philosophy — trained themselves and fought daily in public to become autarchic, free and happy. Antisthenes, Diogenes, Crates, Metrocles and his sister Hipparchia - also the wife of Crates - were the best representatives of this heroic and provocative cynicism of the first generations. Later on, in the Hellenistic period, the challenge was handed down to figures like Menippus and Bion, but their approach was of a more literary and satirical nature and did not necessarily imply a thorough commitment in real life. Finally, in the Imperial era Cynics of a far less authentic kind appeared, who wore the philosopher's garment only to dissimulate the wickedness of the parasite.

KeYwords: Ancient cynicism, Socraticism, Ethics, Individualism, Nature, Simplicity, Self-sufficiency, Defacing the recoining values, Asceticism, Training, Will, Indifference, Freedom, Happiness, Antisthenes, Diogenes, Crates, Metrocles, Hipparchia, Mennipus, Bio. 


\section{Cinismo antiguo y cinismo moderno}

La palabra «cinismo» del lenguaje común nos evoca hoy la actitud de quien no acepta nada ni a nadie como sagrado y, movido por la pura indiferencia o el mordaz sarcasmo, se complace en utilizar palabras provocativas e insultantes para referirse a valores y sentimientos admitidos o incluso reverenciados por los demás; y, más aún, no duda en servir a sus propios fines sin importarle los medios empleados. Se trata de una actitud marcada no precisamente por un heroico y desafiante atrevimiento social ni menos aún por un compromiso ético firme, rasgos que caracterizaron, en cambio, a aquellos lejanos filósofos griegos del s. IV a.C. que fueron los primeros a los que se dio el apelativo de "cínicos» (Кvvikoí),

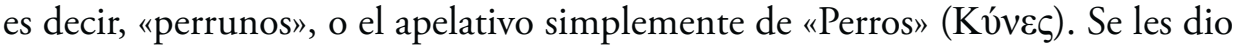
sin duda de modo peyorativo, y, sin embargo, ellos lo asumieron como el mejor timbre de la sabiduría y de la vida que preconizaban y practicaban. Al abordar el

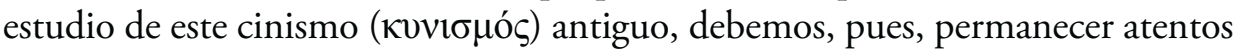
contra toda fácil asimilación basada en la evocación del cínico moderno, como, en general, de otras figuras de nuestro tiempo, como los hippies surgidos en los últimos años de la década de $1960^{2}$.

Lo importante es no confundir en modo alguno el cinismo antiguo con el moderno y, en general, asumir la polisemia inherente al término. De hecho, ya en la misma Antigüedad las etiquetas de "cinismo» o "cínico" pudieron cubrir actitudes muy diversas. Sobre todo, en la época del Imperio romano hubo quienes adoptaron para sí el calificativo de «cínicos» sin que ni su vida ni su pensamiento fueran dignos del nombre que llevaron sus predecesores. Eran farsantes que utilizaban una indumentaria desaliñada y hacían gala de un comportamiento desvergonzado con el único fin de engańar a los demás y de vivir como simples parásitos de la sociedad, prefigurando así aspectos del cinismo «vulgar» de los tiempos modernos. Autores como Dion Crisóstomo, Epicteto, Luciano o Juliano se encargarían bien de desenmascarar a estos, a sus ojos, falsos cínicos y marcar las distancias con respecto a los cínicos verdaderos, a menudo (como en el caso de Epicteto o Juliano) a costa (hay que señalarlo también) de idealizar no poco a estos últimos, para rehabilitarlos sobre todo en un sentido social y político ${ }^{3}$.

Sobre el cinismo moderno hay que decir también que la actitud que lo define dista mucho de ser simple, y no se agota sin más en la pura desvergüenza

${ }^{2}$ Cf. Shmueli 1970, Windt 1972, Dambska 1973, Xenakis 1973.

${ }^{3}$ Cf. Goulet-Cazé 1990, Billerbeck 1978, Ead. 1982, Ead. 1993, Bouffartigue 1993. 
o desentendimiento del cínico vulgar. Muy al contrario, el cinismo moderno remonta al Renacimiento, hunde en particular sus raíces en la Ilustración del siglo XVIII con figuras tan notables como Rousseau, Voltaire o Diderot, en Francia, Wieland, en Alemania, etc., y tiene, más adelante, ya en el siglo XIX, a uno de sus mejores representantes en Nietzsche ${ }^{4}$.

Hago aquí una mención especial de la Crítica de la razón cínica de Sloterdijk (1989), quien considera el cinismo moderno antirracionalista y desencantado, puramente negativo, como un producto del fracaso práctico de la Ilustración. No en vano, lo define, de modo paradójico, como "falsa conciencia ilustrada»o como «voluntad de saber (entendido como poder) carente de ideales e infeliz». Frente a él, propone como ejemplo transformador para el hombre de un tiempo en crisis el gran cinismo valiente y fecundo de aquellos antiguos filósofos griegos que sí supieron realizar sus vidas en acción iluminadora y liberadora, aquellos cuyo cinismo sí era una ética, lo que supone un ideal de felicidad. De hecho, los movimientos estudiantiles alemanes de los años 1980 se vieron reconocidos en el llamamiento de Sloterdijk, y su libro se convirtió entonces en el más polémico y leído en Alemania. Hoy, más de treinta años después (la versión original es de 1983), cuando no podemos dejar de evocar al respecto por ejemplo el movimiento indignado e inconformista del 15-M, aquel llamamiento de Sloterdijk sigue sin duda teniendo pleno sentido, como la necesidad misma de esa recuperación de lo más auténtico e invariable, de lo más atrevido y desafiante también del espíritu del antiguo cinismo. Incluso desafíos tan modernos como el ecologismo no dejan de mirar hacia nuestros antiguos Perros 5 .

En las páginas que siguen presento una imagen de lo que fueron y significaron los cínicos en la Antigüedad clásica y helenística, del contexto en que surgió su pensamiento y más aún de cómo se materializó vitalmente en la acción filosófica de una serie de individuos. Para ello, resulta imprescindible abordar otra cuestión preliminar, a saber: la de las fuentes que nos han llegado al respecto y que son las que tenemos que utilizar para todo intento de reconstrucción.

\footnotetext{
${ }^{4}$ Cf. al respecto Niehues-Pröbsting 1979, Id. 1980, Id. 2000, Sloterdijk 1989 y Onfray 1990, a los que hay que añadir Clément 2005, sobre el cinismo en el Renacimiento.

${ }^{5}$ Cf. Cuesta 2006, 2011.
} 


\section{El problema de las fuentes sobre el cinismo antiguo}

Se trata de un problema de capital trascendencia, ya que la inmensa mayoría de los textos que nos han llegado sobre los cínicos antiguos constituyen simples testimonios contenidos en la obra de muy diversos autores, de orientación ideológica muy diversa y casi siempre muy posteriores a los cínicos de la primera generación, el siglo IV a.C., es decir, Antístenes de Atenas, Diógenes de Sinope, Crates de Tebas y sus discípulos directos. Los textos que podemos considerar fragmentos propiamente dichos de los cínicos son muy escasos. No es que ellos no cultivaran la literatura, pues, pese a lo que podría pensarse si tenemos en cuenta su fundamental e imperativo rechazo de la cultura tradicional, lo hicieron con cierta frecuencia, aunque siempre desde luego según su particular modo paródico y transgresor ${ }^{6}$. Lo que sucedió, más bien, fue que la índole propia de sus escritos, sobre todo desde el punto de vista moral y social, los destinó a una transmisión directa absolutamente precaria.

A ello colaboró de modo trascendental el que los cínicos no constituyeran nunca una escuela filosófica en el sentido convencional del término, marcada por una línea sucesoria que pudiera garantizar unas condiciones favorables para la transmisión a lo largo del tiempo de la memoria del pensamiento y de la obra de los predecesores. Muy al contrario, el cinismo se mostró desde el principio ajeno a una realidad escolar de este tipo, tan ajeno como a una formación y a una actividad filosóficas basadas en lo puramente intelectual y libresco. Pues bien, uno de los mejores conocedores hoy de la tradición filosófica antigua, Goulet (2007), editor del monumental Dictionnaire des philosophes antiques, cuyos últimos volúmenes verán la luz este año, ha puesto bien de manifiesto la importancia del papel jugado por las escuelas en la transmisión y finalmente en la conservación de los textos filosóficos griegos. Más allá del concepto de conservación, vinculado a una realidad siempre inestable y azarosa, se pone de relieve aquí sobre todo el concepto de transmisión, que implica una voluntad de garantizar el conocimiento, el estudio y la pervivencia de determinados textos. Ante tal realidad, parecía inevitable, por tanto, que los textos de los cínicos fueran objeto de una conservación extremadamente pobre y fragmentaria, más aún si pensamos, como ha insistido también Goulet, que al final de la Antigüedad fueron sobre todo los textos filosóficos que tenían algún interés para las escuelas neoplatónicas de los siglos IV a VI los que se beneficiaron de una regeneración a través de la copia. En efecto, los escritos de los cínicos no parece que jugaran en cuanto tales ningún

${ }^{6}$ Cf. Roca Ferrer 1974, Martín García 2008. 
papel especial en los círculos neoplatónicos. Los neoplatónicos parece que sólo experimentaron un interés particular por los textos de Antístenes, mientras que los demás cínicos no son objeto en sus escritos sino de simples menciones puntuales en tanto que protagonistas de dichos o anécdotas presentados más o menos al margen de su contexto originario.

Antístenes es también el único cínico del que se nos han conservado escritos en transmisión directa. Se trata de dos declamaciones en el estilo de Gorgias, que fuera su maestro antes que Sócrates: Ayax y Odiseo, conservadas en un manuscrito medieval (el Palatinus Graecus 88, del siglo XII) como apéndice a los discursos de Antifonte y al lado de la Helena y del Palamedes de Gorgias y del Odiseo de Alcidamante ${ }^{7}$. En este caso, la pervivencia se debe explicar sin duda por la presencia y la utilidad que ambos textos de Antístenes pudieron tener en las escuelas de retórica.

Nada más nos ha llegado por transmisión directa de los cínicos. Tenemos, por transmisión indirecta, algunos escasos fragmentos de las supuestas tragedias de Diógenes ${ }^{8}$, o de las elegías de Crates, fragmentos transmitidos en autores como Plutarco, Diógenes Laercio, Juan Estobeo, Juliano, etc., o en colecciones anónimas como la Antología Palatina. De la famosa República de Diógenes, que debió de constituir un escandaloso ejercicio de incursión cínica en la tradición de los escritos sobre la organización de la sociedad política que contaba en su haber a filósofos tan ilustres como Platón, sólo tenemos referencias en textos de autores abiertamente hostiles al tipo de planteamientos lanzados aquí por Diógenes ${ }^{9}$. El testimonio más sustancial en este sentido es el del epicúreo Filodemo del siglo I a.C., en los fragmentos de su obra Sobre los estoicos conservados en restos de dos de los rollos de papiro sacados de las cenizas del Vesubio en la célebre Villa de los papiros de Herculano ${ }^{10}$. En esta obra Filodemo atacaba duramente, junto a la República de Diógenes, la obra homónima que habría escrito el fundador de la Estoa, Zenón de Citio, en los tiempos en que siguiera la senda cínica, como discípulo que fuera del discípulo de Diógenes, Crates, cuya vida se adentraba ya en el s. III a.C. (ca. 365-285). Para ello Filodemo no dudaba en presentar como mejor convenía a sus intereses y con el fin de desacreditar a sus adversarios naturales

${ }^{7}$ Cf. Goulet-Cazé 1992.

${ }^{8}$ Se ha ocupado de ellos con finura entre nosotros López Cruces, de quien cito uno de sus trabajos más relevantes al respecto (2010), sobre la tragedia Heracles.

${ }^{9}$ Cf. Goulet-Cazé 2003, Husson 2011.

${ }^{10} \mathrm{Cf}$. Dorandi 1982, 1993. 
estoicos (que se habían encarnizado contra Epicuro y su escuela) los aspectos más escandalosos de ambas obras, eso sí totalmente descontextualizados ${ }^{11}$.

El testimonio de Dion Crisóstomo, discípulo de Musonio Rufo, constituye también, a finales del siglo I y principios del II d.C., un testimonio precioso sobre los cínicos de la primera generación, en particular sus cuatro discursos diogenianos. En efecto, en ellos debió sin duda de utilizar Dion fuentes de gran antigüedad, aunque sin descartar, por supuesto, la confluencia también de elementos más o menos legendarios o novelescos ${ }^{12}$.

Una fuente de extraordinaria importancia para el conocimiento del cinismo y mucho más antigua son los fragmentos de Teles, moralista del siglo III a.C., conservados en la monumental antología que reuniera el ya citado Estobeo en torno al siglo V d.C. ${ }^{13}$. Se trata de textos de una cierta extensión que nos testimonian muy bien lo que pudo ser en plena época helenística la actividad pedagógica de moralistas populares como este Teles, de clara inspiración cínica. Los filólogos alemanes del siglo XIX, para este tipo de testimonios y en general para todos aquellos que reflejaban el modo de filosofar de los cínicos o de filósofos más o menos afines a estos, emplearon el concepto de "filosofía popular», recordando su propia tradición filosófica del siglo XVIII del mismo nombre. Me refiero a la tradición filosófica representada por determinados filósofos que, siguiendo el llamamiento a la «popularización» de la filosofía lanzado por Diderot, impulsaron entonces una concepción socrática de la filosofía no encerrada en los límites de un espacio escolar sino abierta en el dominio público, en una relación directa con sus contemporáneos, y más allá de la oposición entre teoría y práctica ${ }^{14}$. Entre las principales figuras de esta "filosofía popular» moderna estuvieron JohannAugust Ernesti, Johann Gottfried Herder, o los filósofos del grupo de Berlín, sobre todo Friedrich Nicolai, Johann Jakob Engel o Moses Mendelssohn. Todos ellos se empeñaron en sacar a la filosofía de las Universidades y ponerla al servicio de la vida y del hombre ordinario. Evidentemente, tal movimiento no tardó en suscitar la oposición enconada de los filósofos académicos, desde Immanuel Kant y su escuela hasta Georg Friedrich Hegel, que negaban la pertinencia del concepto mismo de «filosofía popular», y situaban la filosofía en el dominio de la

${ }^{11}$ Cf. Goulet-Cazé 2003, Husson 2011, pp. 33-40.

${ }^{12}$ Cf. Brancacci 1977, 1980.

${ }^{13}$ Cf. Fuentes González 1998.

${ }^{14}$ Cf. Fornet-Betancourt 2002, pp. 175-267; Böhr 2003. 
más pura especulación teórica ${ }^{15}$. Por supuesto con todas las diferencias de rigor, podemos constatar la analogía esencial que presentaba esta situación con la de los cínicos del siglo IV a.C., y no deja de ser significativo que Hegel manifestara en su historia de la filosofía un desprecio absoluto por el cinismo, así como por todos los filósofos que sólo nos son conocidos por noticias de tipo biográfico y anecdótico, y no por desarrollos doctrinales en sentido estricto. Para una revalorización filosófica del cinismo similar a la de la Ilustración habría que esperar a la obra del ya citado Nietzsche en el último tercio del siglo XIX, quien, como filólogo clásico, no en vano manifestó por cierto un interés muy particular por el estudio de nuestra principal fuente biográfica sobre los cínicos: las Vidas y doctrinas de los filósofos ilustres de Diógenes Laercio, obra que la crítica suele datar en la primera mitad del siglo III d.C., pero en la que su autor reunió materiales de muy diversa procedencia que ilustran de un modo sin igual la influencia de toda una rica tradición anterior de origen helenístico. Se contaban aquí, además de escritos pertenecientes en general a la tradición biográfica, otros que trataban más en sentido estricto sobre las doctrinas filosóficas (placita, tratados sobre las sectas), así como obras sobre las sucesiones de escolarcas. Son el tipo de obras que se suelen calificar con el neologismo de "doxográficas», acuñado por H. Diels a finales del siglo XIX ${ }^{16}$.

Encontramos a los cínicos asimismo de modo abundante en la rica tradición gnomológica. Al respecto baste recordar de nuevo la antología de Estobeo. En obras de este tipo aparecen nuestros filósofos como personajes recurrentes portadores de dichos y protagonistas de todo tipo de anécdotas moralizantes, ciertamente enmarcados en contextos pedagógicos que obedecen a los intereses concretos de los recopiladores ${ }^{17}$.

Desde un principio, los cínicos parecían destinados a no tener sino una influencia muy limitada en el espacio y en el tiempo, y ello debido a la singularidad de su filosofía. Esta se expresaba consciente y plenamente a través de una ética al servicio de la vida cotidiana del individuo, mediante un mensaje que se presentaba abiertamente a contracorriente, y no resultaba nada fácil ni de realizar ni de recibir, y menos aún de retener. Lo que los cínicos dijeron y escribieron efectivamente a sus contemporáneos formaba parte de un empeño contracultural que sólo difícil y muy parcial y distorsionadamente pudo tener reflejo en la

\footnotetext{
${ }^{15}$ Cf. Hegel 1990, p. 99 ss.

${ }^{16}$ Cf. Runia 1999.

${ }^{17}$ Cf. Fuentes González 2011.
} 
cultura que era objeto en cada momento de transmisión, a través de autores que tradujeron esta contracultura en términos más respetables (comenzando ya quizá por un Teles, y más tarde por autores como Musonio y Epicteto), o bien a través de antologías donde las palabras y las ideas de los cínicos aparecían encuadradas en contextos que resultaban más fácilmente controlables o maleables.

Al margen de este tipo de transmisión, la voz de los cínicos antiguos estaba sin duda prácticamente condenada al más absoluto silencio. Pese a todo, incluso si su voz no es para nosotros sino un eco que resuena a través de los autores más diversos, un eco a menudo mal reproducido, por no hablar de los casos de los adversarios declarados, paganos o cristianos, en quienes este eco ha sido claramente objeto de falseamiento, dicha voz no ha dejado de escucharse a lo largo de los siglos. En efecto, estos hombres, que aspiraban a cambiar la realidad a través de la sola transformación radical de sus propias vidas individuales, han estado constantemente presentes, dando a sus contemporáneos y a las generaciones venideras materia para pensar, para poner en duda los principios recibidos e intentar comprender la consistencia y el sentido de la auténtica vida humana, del auténtico hombre, ese que Diógenes buscaba con su legendario candil en pleno día, mostrando así que era empeño harto difícil (SSR V B 272). He ahí sin duda la principal misión de toda "filosofía popular», y ha sido en el seno de lo poco que nos ha llegado de la «filosofía popular» antigua donde este primer y genuino cinismo ha logrado sobrevivir, por más que difícil y fragmentariamente.

\section{3. ¿EI cinismo como filosofía?}

Vinculada a lo expuesto, otra cuestión importante en torno al cinismo es su condición o no de filosofía propiamente dicha. Ya los antiguos se hicieron este planteamiento desde época helenística, como testimonia Diógenes Laercio (I 19), cuando se opone a un autor como Hipóboto (su datación fluctúa entre finales del siglo III y finales del I a.C.), que negaba que el cinismo constituyese

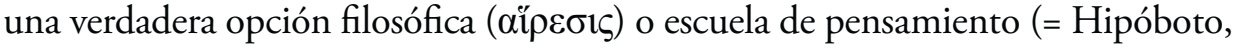
fr. 1 Gigante). Por su parte, Diógenes Laercio (VI 103) defendía que la filosofía cínica debía ser considerada también como una escuela de pensamiento y no sólo, según pretendían algunos, como un simple posicionamiento vital ("̌v $\sigma \tau \alpha \sigma ı \varsigma$ Bíov), una actitud práctica ante la vida. Se suele atribuir esta caracterización del cinismo como un posicionamiento vital a la misma figura de Hipóboto, aunque el testimonio laerciano la atribuye en general a un impreciso «algunos». Diógenes Laercio se limita en cualquier caso a negar esta opinión en un párrafo en que, 
por su parte, enumera, siquiera en escasas líneas, las doctrinas comunes que, a su juicio, pueden justificar la consideración del cinismo como verdadera escuela de pensamiento ${ }^{18}$.

Al parecer, el criterio que un autor como Hipóboto utilizaba para dejar al cinismo fuera de la categoría de escuela filosófica no era otro que el carecer de un corpus de doctrina, y en el fondo no parece que haya que ver aquí sino una discusión de tipo más o menos técnico de la historiografía filosófica. En el marco de este debate erudito, determinados historiadores antiguos (como hiciera también un Hegel en los tiempos modernos) pudieron considerar que el cinismo adolecía (con respecto a las otras filosofías) de una pobreza o fragilidad doctrinal que hacía que debiera ser considerado, a sus ojos, más que como una verdadera opción filosófica, como una simple disposición o posicionamiento existencial. Otros sin duda pudieron manifestar al respecto menos escrúpulos y exigencias de tipo técnico, o bien considerar (como Diógenes Laercio) que no se podía negar que el cinismo tuviera unos mínimos principios doctrinales de base.

El hecho de que los cínicos se concentraran directamente en la ética, y dejaran del todo de lado las otras partes de la filosofía de entonces, la lógica y la física, debió sin duda de llamar la atención. No en vano a la propia Antigüedad remonta la idea según la cual el cinismo sería un «atajo hacia la virtud (felicidad)», por comparación con la vía larga de sus herederos estoicos, que pasaba, esta sí, por la física y por la lógica, además de presentar finalmente en la ética una mayor y más sutil teorización ${ }^{19}$.

El cinismo, en cuanto que ética y sólo ética, y por más que sus principios puedan parecer simples y poco elaborados y estuvieran focalizados directamente a la práctica, debe ser considerado una filosofía en el pleno sentido de la palabra. Y esta es de hecho la visión de la crítica actual sobre el cinismo, una crítica que ha sabido dignificar la posición de los cínicos en las historias de la filosofía antigua, rescatándolos del ostracismo, o, en el mejor de los casos, de la simple

\footnotetext{
${ }_{18}$ Sobre esta polémica en la Antigüedad interesa asimismo el testimonio (transmitido por Agustín, La ciudad de Dios XIX 1, 2-3) de Varrón (s. II-I a.C.), que reducía a los cínicos a simples defensores de un modo de vida que, en su opinión, podía ser adoptado también por los seguidores de cada una de las escuelas filosóficas por él distinguidas, de tal forma que, según este planteamiento, cada una de estas escuelas (incluidas la platónica o la aristotélica) podían tener una versión cínica si se adoptaba por el filósofo en cuestión el modo de vida cínico. Sobre ambos testimonios de Hipóboto y Varrón, véase Goulet-Cazé 2014, pp. 65-69. ${ }^{19}$ Cf. Goulet-Cazé 1986a (2001²), pp. 22-28; Ead. 2014, pp. 43-48.
} 
marginalidad anecdótica. A lo largo de todo el siglo XX, y de modo especialmente fecundo desde los ańos 1980, los cínicos han sido objeto de un interés creciente, serio y autónomo, por parte de la crítica, y hoy contamos, amén de la monumental recopilación de testimonios por parte de Giannantoni, en sus Socratis et Socraticorum Reliquiae ${ }^{20}$, con un amplísimo corpus crítico que, sin estar exento por supuesto de polémica en determinados aspectos ${ }^{21}$, nos permite conocer mejor la aportación de estos filósofos a la historia del pensamiento, y cómo los cínicos no pueden ser despachados sin más al plano de lo curioso, extravagante y anecdótico en filosofía ${ }^{22}$.

\section{El cinismo, una filosofía prehelenística y socrática}

Es evidente que la cínica debe ser analizada como una filosofía prehelenística, surgida en el siglo IV a.C., siglo que en la filosofía (como también en la elocuencia) constituye la época clásica, y que en la filosofía, como de nuevo en la elocuencia, está focalizado en la ciudad de Atenas. Se trata de un siglo caracterizado por la crisis progresiva de las polis, hasta la consolidación de la hegemonía de Macedonia en la segunda mitad del siglo. Y se trata, por tanto, de un largo período de transición hacia lo que será plenamente el Helenismo ${ }^{23}$. Es en este siglo IV de crisis, trágicamente marcado en sus inicios por la muerte en Atenas de la monumental figura de Sócrates (399), donde debemos situar el nacimiento del desafío cínico.

Como ha destacado Teodorsson ${ }^{24}$, el cinismo «es la más extrema y particular de las líneas de pensamiento que evolucionaron en Atenas después de la muerte de Sócrates», y era la suya una tendencia diametralmente opuesta a la de Platón o Aristóteles, que se concentraron en la búsqueda del conocimiento del ser humano y del mundo en todos sus aspectos, con el objetivo de presentar una base teórica estable para una ética y política óptima (mediante una mejor comprensión de la psique humana) y también (mediante un mejor conocimiento de la naturaleza) para una vida más conveniente desde el punto de vista material, unido todo ello

\footnotetext{
${ }^{20}$ Socraticorum Reliquiae, 1983-1985; Socratis et Socraticorum Reliquiae (SSR), 1990.

${ }^{21}$ Cf. Fuentes González 2013.

${ }^{22}$ Cito alguna de las mejores síntesis: Goulet-Cazé 1986a (2001²), Ead. 1993b, Ead. 2010, Ead. 2014, 9-97, Ead. \& Goulet (ed.) 1993, Branham \& Goulet-Cazé (eds.) 2000, Desmond 2008, Navia 1996, Id. 1998, Id. 2001, López Cruces 2015.

${ }^{23}$ Sobre el concepto de filosofía postaristotélica o helenística, $c f$. Isnardi Parente 1985-1986.

${ }^{24}$ Cf. Teodorsson 2007, p. 49.
} 
al intento (mediante el pensamiento lógico y especulativo) de una interpretación metafísica y religiosa del universo en su totalidad. Según Teodorsson, frente a esta actitud investigadora y a esta actividad positiva y optimista que conformaba un ambicioso programa social y civilizador, el cinismo puede ser caracterizado en el polo opuesto: en lugar de tratar de mejorar y reformar la situación actual de las condiciones de la vida humana y de la política, los cínicos rechazaron radicalmente todas las instituciones de la sociedad, a su juicio puramente artificiales y perniciosas para el individuo. Lo que a su vez propusieron fue concentrar toda la atención en el individuo mismo, con el fin de que este pudiera alcanzar la auténtica excelencia humana ( $\dot{\alpha} \rho \varepsilon \tau \eta ́)$, encarnada por ellos, como veremos, de un modo muy peculiar.

Pues bien, hay que insistir en la importancia de Sócrates en el surgimiento del cinismo. No en vano Antístenes, el fundador de esta filosofía según todas las evidencias que nos han llegado de la Antigüedad, fue discípulo directo suyo ${ }^{25}$. Se nos dice, en efecto, que era ateniense, aunque no de pleno derecho por ser de madre extranjera (tracia), y que tras un contacto (quizá no muy dilatado) con la retórica a través de Gorgias, quedó deslumbrado por la filosofía al conocer a Sócrates. Nuestros testimonios presentan esta relación como marcada por una fuerza que llevaba a Antístenes, que vivía en el Pireo, a recorrer diariamente una larga distancia para escuchar a Sócrates, de quien le atraía sobremanera su

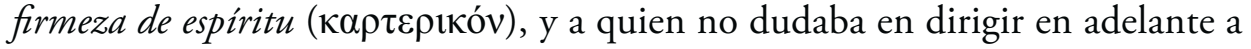
sus propios discípulos, convirtiéndose así en condiscípulo de los mismos junto al nuevo maestro ${ }^{26}$.

Según Jenofonte ${ }^{27}$, Sócrates admiraba de Antístenes su capacidad para poner en contacto a los individuos entre sí, una habilidad que Sócrates comparaba con la del alcahuete-proxeneta, y Antístenes habría terminado por considerar esta comparación como el mayor de los elogios, y la expresión de la posesión de un alma absolutamente rebosante de riquezas. El saber tratar y conversar con los hombres representa ciertamente una clave de unión entre Antístenes y Sócrates. Ya en un testimonio relativo a su obra retórica vemos a Antístenes elogiando la virtud odiseica de «saber tratar a los hombres de muchos modos» (SSR V A 187). En realidad, se trata de un saber que tenía como fin el propio sujeto mismo, y así

\footnotetext{
${ }^{25} C f$. de nuevo Fuentes González 2013.

${ }^{26} C f$. Diógenes Laercio VI 1 (SSR V A 12).

${ }^{27}$ Cf. Jenofonte, Banquete 4, 61-64 (SSR V A 13).
} 
se nos dice que a quien le preguntó qué beneficio había obtenido de la filosofía, Antístenes le respondió: «el poder tratar conmigo mismo» (SSR V A 100).

$\mathrm{Al}$ respecto de la habilidad de Antístenes en el trato con los demás, merece mención especial el testimonio de Teopompo de Quíos (SSR V A 22), historiador del s. IV a.C., contemporáneo suyo por tanto, que afirmaba de aquél que «impresionaba su habilidad para seducir a cualquiera por el tono ajustado de su trato» (de su conversación). Es más, Teopompo, que era contrario al idealismo platónico como el propio Antístenes, afirmaba en su obra Contra las enseñanzas de Platón que Antístenes era el único de los socráticos que le merecía respeto y admiración.

La relación entre Antístenes y Sócrates no debió, sin embargo, de estar exenta de tensión. En Jenofonte vemos, por ejemplo, a Sócrates manifestando su malestar y su recelo ante el «carácter difícil» de Antístenes, un carácter que, reconociendo admirar en otros sentidos, declara sobrellevar mal por la vehemencia de la atracción que hacia él sentía su discípulo y que al parecer no se limitaba al atractivo espiritual ${ }^{28}$. Que Sócrates no retrocedía ante el reto de los caracteres difíciles lo sabemos por las numerosas anécdotas sobre su esposa Jantipa. De hecho, el propio Antístenes, según el mismo Jenofonte, le reprochaba el tener trato con mujer tan sumamente insoportable, a lo que Sócrates le habría respondido que de ese modo, si era capaz de convivir con ella, estaba seguro de poder hacerlo con cualquier otra persona ${ }^{29}$. Y otras anécdotas nos muestran una especie de rivalidad de Antístenes con Sócrates por poner públicamente de manifiesto su fortaleza y capacidad de resistencia y de asunción de la pobreza, como cuando se nos dice que Sócrates le reprochaba el revelar un cierto amor por la fama $(\varphi \imath \lambda o \delta o \xi i ́ \alpha)$ al ir enseñando de un modo ostentoso la parte rota de su tabardo, como si el discípulo quisiera poner así de manifiesto que superaba en ello el modelo representado por su maestro (SSR V A 12).

Al margen de estos aspectos más o menos anecdóticos, parece claro que Antístenes admiraba y se sentía sobre todo atraído por la fortaleza de espíritu de Sócrates, y no en vano su propio pensamiento ético girará en torno a los

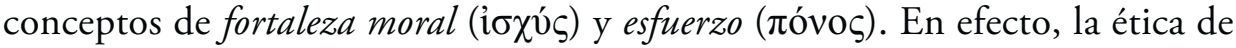
Antístenes parte del principio de que la virtud es enseńable y, una vez adquirida,

${ }^{28}$ Cf. Jenofonte, Banquete 8, 4-6 (SSR V A 14).

${ }^{29}$ Cf. Jenofonte, Banquete 2, 10 (SSR V A 18). Curiosamente este prepararse a conciencia para poder afrontar mejor experiencias ulteriores es un rasgo presente en numerosas anécdotas sobre los cínicos. 
no se puede perder, que basta para procurar la felicidad, que es cosa de hechos y no precisa de muchas palabras ni conocimientos, que es un arma que nadie nos puede arrebatar, y que de este modo la sabiduría práctica ( $\varphi \rho o ́ v \eta \sigma i \varsigma)$ se convierte en la vida de los individuos en la más segura de las murallas (SSR V A 9, 134). En este sentido, la imagen del combatiente de la virtud es muy característica de Antístenes, y es Heracles enfrentado a sus célebres trabajos el héroe mitológico por excelencia en el cual se ven reflejados los cínicos en su andadura basada en el esfuerzo y la superación. Este héroe se convirtió de hecho en una especie de santo patrón del cinismo, ya desde Antístenes (SSR V A 3, 26, 96, 99, V B 584). Y hablar de esfuerzo no es para un cínico sino hablar (con un símil deportivo,

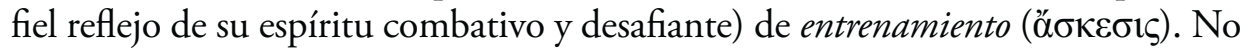
se trata de saber lo que se debe hacer, sino de hacerlo, y de curtirse en ello día a día, y nuestro anecdotario cínico nos ofrece numerosos ejemplos de ello, protagonizados en particular por Diógenes, aunque se trata de un principio que ya está en el propio Antístenes. Diógenes insistirá en la importancia capital de este continuo entrenamiento en la realización de la filosofía cínica (SSR V B 291): un entrenamiento con base siempre corporal pero supeditado a una finalidad moral ${ }^{30}$. Él entrena su cuerpo para hacerse fuerte frente a las penalidades ( $\pi$ óvol), distinguiendo claramente entre las inútiles, que son, entre otras, las que pasan los atletas corrientes, y las útiles, las que ayudan a los atletas de la virtud a vencer adversarios auténticos como la pobreza, el hambre o el frío. El entrenamiento del cuerpo es para Diógenes un medio para vencerlos, para aprender a soportarlos mejor o para convertirlos incluso en sus aliados. Él, el atleta del Ponto, gusta de exhibir su desafío en los Juegos más relevantes, como en los de Olimpia, donde, corriendo a la zaga en la carrera de hoplitas, se proclama a sí mismo vencedor

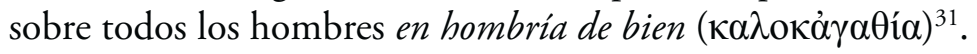

En la búsqueda de la verdad, Antístenes debió sin duda de concluir que los razonamientos lógicos no tenían nada que aportar. Es bien conocido que sus planteamientos nominalistas fueron objeto de la más absoluta ridiculización por parte de Platón o Aristóteles ${ }^{32}$. Lo que para él valía en cualquier caso era la virtud, autosuficiente para la felicidad y que no precisaba de nada más que de fortaleza socrática. La crítica ha querido ver en esta declaración de la importancia del esfuerzo por parte de Antístenes una ruptura del intelectualismo socrático

\footnotetext{
${ }^{30}$ Remito al libro ya clásico de Goulet-Cazé 1986a (2001²), en particular pp. 53-71.

${ }^{31}$ Cf. Máximo de Tiro XXXIV 9 (SSR V B 177); Pseudo-Demetrio de Falero, Sobre el estilo 260 (SSR V B 449).

${ }^{32}$ Cf. Brancacci 2005, 151-171, pp. 195-223.
} 
(según el cual la virtud se reduciría al conocimiento y las malas acciones a un error de juicio). De todas formas, no debemos pasar por alto que la tradición nos muestra a un Sócrates que pone también de manifiesto la importancia del componente práctico en la ética, por lo que hablar de una ruptura del intelectualismo socrático en Antístenes parece tener una consistencia muy relativa ${ }^{33}$. Lejos quedaron ya, por lo demás, los enfoques monolíticos de la figura de Sócrates, que debe ser contemplada en la riqueza polifónica que nos muestran nuestras diferentes fuentes.

En cualquier caso, el Antístenes socrático no es incompatible en modo alguno con el cínico. En su relación, tensa y compleja, con Sócrates pudo ciertamente dar con una vía filosófica propia que en un determinado momento se reconociera como un nuevo camino que acabaría denominándose como cínico. De hecho, Antístenes debió de ser el primero en ser llamado Perro, y en este sentido resulta revelador el pasaje de la Retórica de Aristóteles en que este utiliza el apelativo refiriéndose, como acertadamente ha demostrado Goulet-Cazé, a nuestro filósofo ${ }^{34}$.

En definitiva, como se ha señalado también con acierto ${ }^{35}$, las paradojas de Antístenes (la imposibilidad de la contradicción, la imposibilidad asimismo de la definición de la esencia, la visión de la virtud como suficiente para la felicidad, la preferencia de la locura al placer) eran respuestas extremas a cuestiones socráticas: la búsqueda de la definición, por un lado, y la reivindicación de la verdadera felicidad, por otro. Y la intención de Antístenes con estas paradojas debió de ser sobre todo llamar la atención sobre la futilidad del discurso lógico y sobre el carácter extraño de la senda hacia la felicidad.

La personalidad compleja de Antístenes debe sin duda disuadirnos de forjar interpretaciones demasiado cerradas y unívocas. Me refiero en particular a la de Brancacci 2005, quien se sirve de la reflexión antisténica sobre el logos como único factor de reconstrucción de la doctrina subyacente en nuestros testimonios. Esta imagen de un Antístenes intelectualista y dogmático consagrado (aunque consciente de la importancia de la práctica) a sus investigaciones sobre el logos parece responder a un deseo de alejarse a toda costa de la imagen de un Antístenes cínico (prejuzgada sin duda como menos seria y filosófica). Semejante reconstrucción no tiene debidamente en cuenta toda la complejidad y riqueza de

${ }^{33}$ Cf. Brancacci 2005, p. 82.

${ }^{34}$ Cf. Aristóteles, Retórica III 10, 1411a 24-25 (SSR V B 184); Goulet-Cazé 2000.

${ }^{35}$ Cf. Prince 2006, 77. Véase asimismo Navia 2001, cap. 6. 
nuestra tradición, en particular en lo que se refiere al papel sin duda fundamental del esfuerzo y del ejercicio en la filosofía de Antístenes.

Por lo demás, a través de Antístenes, la tradición socrática debió de seguir perviviendo en Diógenes, por más que la crítica moderna no deje de manifestar ciertos escrúpulos sobre la posibilidad del carácter consciente y voluntario de tal perspectiva socrática en Diógenes y sus discípulos ${ }^{36}$. De hecho, aunque se pueda sospechar de la autenticidad de la proverbial imagen de Diógenes como «un Sócrates enloquecido» a los ojos de Platón, si fue gestada en época más o menos tardía $a^{37}$, ello no impide reconocer que dicha imagen reflejara fielmente la realidad de aquella compleja filiación socrática del cinismo, interpretado muy acertadamente como un socratismo llevado a sus consecuencias más extremas.

\section{La cuestión del cinismo de Antístenes y de su relación con Diógenes}

Sobre el cinismo de Antístenes hay que mencionar la pretensión de buena parte de la crítica más especializada según la cual dicho cinismo no sería sino una invención a posteriori, como también la relación entre Antístenes y Diógenes (quien, según esta interpretación sería de hecho el primer cínico), una pretensión que no duda en oponerse a toda nuestra tradición antigua. En efecto, esta coincide en afirmar la existencia de dicha relación de magisterio entre Antístenes y Diógenes, y hasta principios del siglo XX a ningún crítico se le había ocurrido ponerla en duda. Así, un autor como Hegel no dejaba en modo alguno de presentar a Antístenes como el fundador del pensamiento cínico y el maestro de Diógenes. Es cierto que nuestra fuente más antigua al respecto, Dion Crisóstomo, nos sitúa ya en época imperial, concretamente en el siglo I-II d.C, pero, como sabemos, esto por desgracia resulta frecuente en lo que tiene que ver con nuestro conocimiento de los cínicos. Poner en duda esta tradición supone poner en duda una afirmación, la del magisterio entre Antístenes y Diógenes, que tenían del todo clara autores de la relevancia del citado Dion Crisóstomo, cuyo testimonio merece en esencia la máxima confianza. En un trabajo reciente he intentado demostrar la consistencia de la tradición antigua sobre la relación (aunque tensa) entre Antístenes y Diógenes frente a la inconsistencia de los

\footnotetext{
${ }^{36}$ Cf. Goulet-Cazé 1993b, p. 293.

${ }^{37}$ Cf. Eliano, Historias varias XIV 33 (SSR V B 59). Como añadido tardío suele omitirse la misma expresión en Diógenes Laercio, Vidas y doctrinas de los filósofos ilustres VI 54.
} 
distintos argumentos esgrimidos en contra por la crítica moderna, trabajo al que remito, por tanto, para los detalles sobre esta cuestión ${ }^{38}$.

Como ya he dicho, los cínicos antiguos no constituyeron nunca una escuela propiamente dicha, con relaciones de magisterio convencionales. Es más, al menos en los primeros tiempos, no manifestaron en realidad ningún empeño proselitista. El ejemplo por excelencia al respecto es el modo como Antístenes, después de haber emprendido la senda del cinismo y consciente sin duda de la dificultad que suponía la realización de esta verdadera filosofía propia de un seguidor espiritual de Heracles, se negaba a aceptar discípulos, en cuya real disposición no confiaba, hasta que la pertinacia de Diógenes acabó convenciéndolo de permitir que lo siguiera, después de numerosas muestras patentes de su mejor disposición a asumir el desafío (SSR V B 19). Y fueron raros sin duda los individuos dispuestos a afrontar el desafío del verdadero cinismo. Con todo, el ejemplo impactante que la actuación de los cínicos supuso sobre otros individuos que acabaron abrazando el cinismo fue trazando relaciones de atracción y de admiración que se convirtieron en un especial modo de amistad y magisterio, aunque cada cínico se sabía radicalmente solo ante los retos constantes de su andadura filosófica ${ }^{39}$.

Aceptando, por supuesto, los componentes ficticios y legendarios propios de la tradición biográfica, nada nos autoriza a poner en duda la imagen general de un Antístenes que, sin identificarse necesariamente de modo pleno con lo que sería pronto la imagen de un Diógenes (ya cínico sin casa y sin patria), bien pudo resultar también chocante y desafiante en el panorama filosófico de la época como para que aceptemos que los testimonios biográficos que nos han llegado al respecto en la tradición puedan tener un fondo de veracidad y de realidad. Nada impide, en efecto, reconocer como verídica la imagen de un Antístenes al que el propio Diógenes bien pudiera haber querido imitar hasta llegar a superarlo en la práctica, como vimos que quisiera también hacer Antístenes con su maestro Sócrates. Por lo pronto, si, como es notorio, Diógenes carecía de casa, parece lógico pensar que hubiera tenido en su caso mayor utilidad el tabardo plegado, convertido en cobertor para dormir, como se cuenta en uno de los relatos etiológicos al respecto (SSR V B 174). En todos ellos parece patente el recurso a elementos ficticios, como cuando se dice que Diógenes habría terminado por vivir en el célebre tonel del ágora ateniense porque alguien a quien habría escrito

${ }^{38}$ Cf. Fuentes González 2013.

${ }^{39}$ Cf. Fuentes González 2003. 
encomendándole que le buscara una casa pequeña se habría demorado demasiado en hacerlo (SSR V B 174).

\section{Las claves del desafío de los primeros cínicos}

La asunción de la pobreza ( $\pi \varepsilon v i ́ \alpha)$ como modo de vida basado en la frugalidad y la simplicidad está por supuesto en relación con toda esta indumentaria externa, pero lo está en un plano mucho más profundo con el concepto de esfuerzo ( $\pi$ óvos), que no en vano comparte con aquella la misma raíz etimológica. Era de hecho la condición y acompañante natural del cínico. Los griegos antiguos ya habían ensalzado el valor de la pobreza, en particular en el ámbito militar, y así decía un autor como Heródoto (VII 101), en el contexto del relato de las guerras médicas, que los griegos habían tenido siempre a la pobreza como "compañera de cría» ( $\sigma u ́ v \tau \rho o \varphi \circ \varsigma)$. Lo que los cínicos hacen en cualquier caso es convertir a la pobreza en una exigencia de la vida auténtica, de la vida filosófica, como la única garantía posible del ejercicio autónomo de la virtud ${ }^{40}$. La riqueza de un individuo radica en esta virtud, y por ello el cínico, propugnando la pobreza, está invalidando completamente los valores y las relaciones de dependencia en las que se sustenta la sociedad convencional.

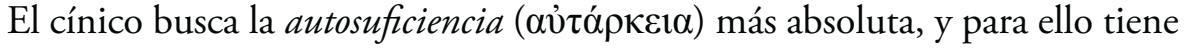
que construirse su propio ser como un ámbito lo más al abrigo posible de todo condicionamiento y dependencia externos. Se desprenderá para ello de toda posesión de los mal llamados bienes materiales, y en este sentido el ejemplo por excelencia es el de Crates, que, perteneciendo a una familia acomodada, lo dejó todo para abrazar la filosofía (SSR V H 4-16). En Diógenes Laercio (VI 87-88) confluyen tres versiones que describen acciones distintas de Crates a la hora de desposeerse de su patrimonio: la venta y el reparto altruista; el abandono y el desecho puro y simple; y, por último, el depósito condicionado al carácter futuro de sus hijos. El resto de nuestras fuentes repite una u otra de estas versiones, con alguna variante, o bien armoniza varias de ellas. La más corriente es la segunda, que no por ello debe considerarse libre de sospecha de contener elementos legendarios o simples lugares comunes. En cuanto a la tercera, la del banquero-notario, hay que señalar en cualquier caso que en ese momento no parece que tuviera Crates ni mujer ni hijos. Sea como fuere, todas nuestras fuentes coinciden en un dato muy significativo: en el hecho de poner en boca de Crates una proclama

${ }^{40}$ Sobre el tema de la pobreza entre los cínicos, $c f$. Desmond 2005. 
solemne al renunciar a sus riquezas, como si estas lo hubieran esclavizado hasta entonces y él, desprendiéndose de ellas, se manumitiese a sí mismo y lo hiciera de modo enfático y solemne públicamente, como un desafío.

Para garantizar esta libertad ( $\dot{\varepsilon} \lambda \varepsilon v \theta \varepsilon \rho i ́ \alpha)$ auténtica, que no se identifica con el verse libre de la condición servil tal como es entendida por la gente común, el cínico se mantiene al margen de la sociedad, por más que su existencia se desarrolle conscientemente en el ámbito de las ciudades, porque es ahí donde su desafío y su ejemplo adquiere toda su significación ${ }^{41}$. Más allá de las creaciones literarias, utópicas y paródicas, del poema de Crates titulado Alforja, con su ciudad insular, frugal y libre de toda amenaza, o de la escandalosa República de Diógenes, el cínico no aspira en modo alguno a crear una nueva sociedad propiamente dicha, sino que su revolución pasa de modo exclusivo por la transformación directa e interior de cada individuo. En este sentido una eventual sociedad cínica no sería sino la coincidencia de una serie de actitudes individuales.

El cínico que sin duda más apegado permaneció a la sociedad de su tiempo fue Antístenes, aunque con grandes reticencias (SSR V A 121). Según uno de los dichos que se le atribuyen, preguntado acerca de cómo hay que acercarse a la política, dijo: «Como al fuego: ni demasiado cerca para no quemarte, ni demasiado lejos para no helarte» (SSR V A 70). Ahora bien, el testimonio fundamental al respecto es el que le atribuye la afirmación de que «el sabio participará en la vida pública no según las leyes establecidas (vó $\mu \mathrm{o}$ ) sino según la ley de la virtud» (SSR V A 134). Al primar de este modo la virtud interior sobre las leyes convencionales, Antístenes pone de manifiesto el carácter rupturista de sus enseñanzas con respecto a los valores establecidos. De hecho, la «reacuñación de los valores» ( $\tau$ ò vó $\mu 1 \sigma \mu \alpha \pi \alpha \rho \alpha \chi \alpha \rho \alpha ́ \tau \tau \varepsilon ı v)$ de que se nos habla con respecto a Diógenes (SSR V B 2-10) tiene, en mi opinión, como correlato en el Antístenes pedagogo aquel «desaprender el mal» del que se nos habla con respecto a él (SSR V A 87). A diferencia de la virtud, que, según Antístenes, no se puede olvidar una vez aprendida, todo lo que la filosofía cínica identifica con el mal no sólo presenta la fragilidad de lo que no tiene un sustento verdadero en la naturaleza humana, sino que, más aún, debe ser olvidado y desaprendido para vivir una vida que garantice la felicidad y la libertad verdaderas del individuo.

\footnotetext{
${ }^{41}$ Los cínicos griegos se distinguen claramente en ello del modelo, en otros aspectos comparable, de los gimnosofistas de la India, que desarrollan su existencia y su ascesis filosófica según la naturaleza retirados de todo contacto social (cf. Estrabón XV 1, pp. 63-65).
} 
Frente a la actitud más ambigua o prudente de Antístenes, Diógenes se nos muestra tajante con respecto al poder y al poderoso: es el cínico el que detenta el auténtico poder, y no sólo no se somete al poderoso, sino que en modo alguno necesita nada de él. Hay que citar al respecto el célebre episodio, sin duda legendario, relatado por Plutarco (Vida de Alejandro XIV 2-5, SSR V B 32), según el cual como Diógenes, que vivía entonces en Corinto, no siguiera la práctica habitual de los grandes hombres del momento de ir a visitar a Alejandro Magno, fue este quien se dirigió allí para visitarlo y se lo encontró tomando el sol; y cuando le preguntó si necesitaba algo de él, se limitó a decirle que se apartara para no hacerle sombra. Más aún, fue Alejandro el que acabó diciendo que, de no haber sido quien era, habría sido Diógenes. El mismo encuentro se evoca en otra anécdota, donde, al presentarse el monarca como "Alejandro, el gran rey", Diógenes lo habría hecho como "Diógenes, el Perro» (SSR V B 34). Diógenes se veía a sí mismo de hecho, viviendo con la sencillez con que vivía al aire libre, pero alternando Atenas y Corinto en función de las estaciones, como el Gran rey de los persas, que pasaba la primavera en Susa, el invierno en Babilonia y el verano en Media: él pasaba el invierno en Atenas y el verano en Corinto (SSR V B 260). De Alejandro se cuenta también otro encuentro, sin duda igualmente ficticio, con Crates (SSR V H 31): tras la destrucción de Tebas (335 a.C.), el monarca le habría ofrecido la posibilidad de reconstruirla, y el cínico le habría dicho que de nada le servía una patria que otro Alejandro podría destruir. Él era «ciudadano de Diógenes», que no estaba expuesto a las intrigas de la envidia.

Los cínicos censuran la cercanía del filósofo con los poderosos y su adulación, practicada abiertamente por el socrático fundador de la escuela hedonista, Aristipo de Cirene, lo que pone de manifiesto cuán alejados pudieron estar en sus posicionamientos quienes compartieron un mismo discipulado en Sócrates. Y así vemos a los cínicos (a través de figuras como Antístenes, Diógenes o Metrocles) enfrentados en determinadas anécdotas con Aristipo (otras veces con su discípulo Teodoro el Ateo, y otras con el mismo Platón), reprochándose mutuamente el no saber llevar la vida más adecuada: una vida frugal, por un lado; una vida cortesana, por el otro (SSR IV A 44-48, SSR IV H 13, SSR V B 56). Y desde luego Diógenes tenía claro lo que valía la amistad de los poderosos. Cuando se le preguntó cómo trataba Dionisio, el tirano de Siracusa, a los amigos contestó: «como a odres: colgando los que están llenos y tirando los vacíos» (SSR V B 56).

El ejemplo máximo entre los cínicos de rechazo de la sociedad y de las instituciones y valores establecidos fue ciertamente Diógenes. Este complementó y radicalizó sin duda de modo decisivo el cinismo de Antístenes con ciertos 
elementos extremos que no estaban presentes, al menos no de modo explícito, en él, sobre todo los que tenían que ver con la desvergüenza y la bestialidad, incluida la aceptación (al menos teórica) de prácticas escandalosas como el incesto etc., a juzgar por nuestros testimonios sobre su República. Estas en cualquier caso no debieron de aparecer, en su contexto genuino, sino como consecuencias extremas de la defensa de la naturaleza ( $\varphi v ́ \sigma i \varsigma)$, que el cínico contrapone a la convención (vó $\mu \circ \varsigma$ ) y hace triunfar sobre ella, como ya hicieran los sofistas del siglo anterior, pero con unos planteamientos y unas consecuencias muy diferentes, que nada tenían que ver, por ejemplo, con la afirmación sofística del dominio del más fuerte sobre los débiles y su realización a costa de estos.

Por lo demás, Diógenes, que era exiliado y al parecer viajó ampliamente por Grecia (Atenas, Corintio, Olimpia, Esparta, Delfos, Egina, Creta), se consideraba

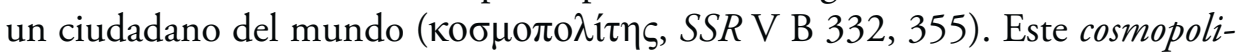
tismo cínico se ha definido normalmente como negativo frente al positivo de los estoicos: no se caracterizaría por la afirmación de una comunidad universal bajo un solo gobierno sino por el rechazo de la pertenencia a una comunidad concreta; toda la tierra es la patria del cínico porque ningún lugar concreto lo es ${ }^{42}$.

${ }^{42}$ Cf. Goulet-Cazé 2003, 29; Husson 2011, 159-163. Según Estrabón (I 4, 9), Eratóstenes, el gran erudito alejandrino del s. III a.C., habría censurado en su Geografía el principio de una división bipartita del género humano en griegos y bárbaros, así como el consejo dado a Alejandro Magno (por su maestro Aristóteles, como precisa Plutarco, Sobre la fortuna o la virtud de Alejandro 329 b-c) de tratar a los griegos como amigos y a los bárbaros como enemigos. Para Eratóstenes, el criterio válido de división debe ser la virtud y la maldad, pues decía- «hay muchos griegos que son gente malvada, y muchos bárbaros poseen una civilización refinada, como los indios o los pueblos de Ariana, o incluso los romanos y los cartagineses, cuyas instituciones políticas son tan admirables». Según él, Alejandro habría desoído en realidad ese consejo, mostrándose igualmente acogedor y benefactor de cuantos hombres notables trató, fueran de donde fueran. Por su parte, Estrabón considera que el monarca sí habría seguido aquel consejo, pero bien entendido, puesto que se trataría en el fondo de oponer el orden, el sentido político y las cualidades que acompañan la buena educación a todo lo contrario. Pues bien, Tarn 1939, apoyándose en el testimonio de Eratóstenes y también en el de Plutarco, que consideraba derivado de este, defendió con firmeza la tesis según la cual la acción misma de Alejandro habría estado movida por la idea de un cosmopolitismo universal. Su universalismo sería así 23 años anterior a la fundación de la escuela estoica por Zenón, cuyo cosmopolitismo habría estado además limitado a los sabios. Esta hipótesis de un Alejandro que sońaba con crear una fraternidad entre todos los pueblos fue rechazada por Badian 1958, que insistía en el carácter cínico-estoico de la concepción universalista. Fue asimismo rechazada por Merlan 1950, quien, alegando el fr. 44B Diels-Kranz de Antifonte, sostenía que no fue Alejandro sino este sofista del s. V a.C. el primero que enunció el principio de la fraternidad humana y de la unidad de la humanidad. Ahora bien, como señala Ramírez Vidal 1998, no se puede concluir que Antifonte sostuviera las ideas 
Por los títulos que se nos han conservado de sus obras (SSR V A 41) y algún testimonio ( $S S R$ V A 58), Antístenes parece que manifestó cierto interés por el matrimonio y la procreación, aunque en la práctica abogaba por la satisfacción libre de las necesidades sexuales, recurriendo al servicio de las prostitutas (SSR V A 56, 82), como hiciera también Diógenes (V B 197, 213-216, 264). En cambio, Crates protagoniza un caso proverbial de matrimonio cínico con Hiparquia de Maronea (Tracia), hermana de su discípulo Metrocles. El episodio según el cual esta bella Hiparquia se enamoró perdidamente de él, que según nuestras fuentes era feo y cojo, pese a los intentos vanos del mismo Crates y de los familiares de la muchacha por disuadirla, pone de manifiesto la fuerza de atracción de estas personalidades cínicas (SSR V H 17, 19, 20-26, 40, V H 1). Al final, Crates acabó cediendo, y se nos dice que ambos consumaban su amor a la vista de todos, ya que vivían en un pórtico público, y a tal unión la llamaron matrimonio

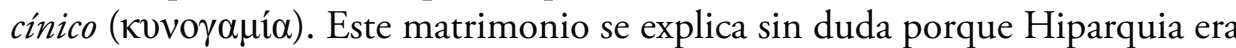
un alter ego de Crates, lo que pone de manifiesto además que en el cinismo la mujer podía ser considerada en un absoluto plano de igualdad con el hombre. La relación entre Crates e Hiparquia representa el ejemplo más acabado de relación

cosmopolitas que serán después características del pensamiento social de los estoicos. Incluso si aceptamos que defendiera el ideal de la igualdad entre los hombres según las leyes de la naturaleza, esa idea no se opondría a la desigualdad entre los hombres por las leyes establecidas por convención. Baldry 1965, 113-127 se opuso también a la hipótesis de Tarn de una convicción consciente por parte de Alejandro en la unidad de la humanidad. En cambio, Bodei Giglioni 1984 rechazó, por su parte, la tesis según la cual los cínicos fueron los precursores del cosmopolitismo helenístico. A su juicio, ellos no tuvieron nunca en perspectiva la monarquía universal de Alejandro (su cosmopolitismo era puramente negativo; $c f$. Baldry 1965, 101-112, que insiste también en el individualismo cínico). Y en el mismo sentido Giannantoni 1988, siguiendo a Tarn, sostuvo que tanto cínicos como estoicos, al menos hasta el final de la época helenística, se mostraron siempre hostiles a Alejandro, como encarnación de los más variados vicios. Sin poder cerrar, por tanto, la cuestión sobre el papel que pudo jugar la acción de Alejandro en la configuración del universalismo helenístico, hay que recordar que el historiador Onesícrito de Astipalea, que fuera discípulo de Diógenes, acompañó al monarca en su expedición por Oriente (como el escéptico Pirrón), y que en su historia de Alejandro, como parte de su retrato del mismo como héroe civilizador, pudo acuñar desde una perspectiva cínica la proverbial imagen del monarca como «un filósofo en armas» y atribuirle la idea de una monarquía universal. En tal caso, desde luego, dicha idea habría sido completamente ajena al cinismo de su maestro Diógenes. En cuanto al cosmopolitismo expresado por Eratóstenes, tampoco podemos descartar que respondiera a una influencia estoica (o cínico-estoica), de su maestro Aristón de Quíos o del propio Zenón. Al respecto, remito a Fuentes González 2000, 195-196. Para una interpretación positiva del cosmopolitismo cínico en el marco de una propuesta de vida conforme a la virtud, como la consecu-

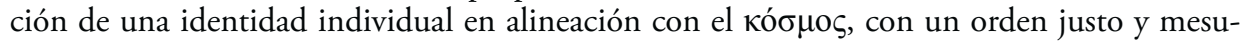
rado, véase Pons Olivares 2009. 
de amistad pedagógica entre los cínicos, para quienes la amistad de hecho no tenía otro sustento que el basado en la asunción de unos mismos principios y un mismo modo de vida. Los simples lazos del afecto no tenían la suficiente fuerza, y el individuo siempre debía primar sobre cualquier transigencia basada en este tipo de lazos de dependencia ${ }^{43}$. No en vano los cínicos propugnaron en el ámbito psicológico la más absoluta insensibilidad e impasibilidad (ả $\alpha \dot{\alpha} \theta \varepsilon ı \alpha$, SSR V A 11, 22).

Dicho esto, en el trato con los demás individuos Crates retomaba sin duda aquella extraordinaria capacidad y sabiduría atribuida a Antístenes. De hecho, se nos dice que sus contemporáneos, por el modo tan afable con que se dirigía a ellos (con una cierta dulzura, que no blandura), lo consideraban como un genio benigno, y así le abrían sus casas, en la confianza de que siempre tenía las palabras más acertadas para llevarles la paz y la armonía (SSRV H 18, 84). Este talante filantrópico debemos sin duda ponerlo en relación con la propia personalidad de Crates, muy diferente en este sentido de la de Diógenes, más dada al empleo de las palabras hirientes y groseras, y al recurso a la retórica del gesto y de la desvergüenza y el impudor como el mejor modo de convencer y disuadir ${ }^{44}$.

Y esta rudeza de Diógenes se pone bien de manifiesto en el episodio según el cual Antístenes, al final de sus días, aquejado de una grave enfermedad, recibió su visita, y, al ver lo mal que su maestro sobrellevaba el trance, y que le preguntaba quién podría librarlo de sus males, le mostró un puñal, diciéndole que parecía estar necesitado de tal amigo (SSR V A 37). La reacción de Antístenes fue decir que pedía librarse de los males, no de la vida, y en este aferrarse a la vida en tales circunstancias Diógenes debió sin duda de ver una actitud inconsecuente de su maestro. Diógenes afirmaba que había sacado de la filosofía el provecho al menos de estar preparado para cualquier azar (SSR V B 360), y el mismo Antístenes decía que no había nada que pudiera coger desprevenido al sabio o dejarlo sin recursos (SSR V A 99, 134). El soportar (de mala manera) una enfermedad incompatible con el autocontrol y que sin duda ponía en riesgo esa muralla infranqueable que se suponía debía constituir para el cínico su saber y su actuar en la virtud, no debía de ser visto por Diógenes como un comportamiento muy coherente de su maestro al final de sus días. En tales circunstancias, el cínico habría debido recurrir al único amigo posible: un puñal como instrumento consciente y autónomo

${ }^{43}$ Cf. Fuentes González 2003. Sobre la reacuñación cínica de la familia en Crates, $c f$. Id. 2015.

${ }^{44}$ Cf. Branham 1993. 
de suicidio, de abandono consciente de la vida cuando esta no está ya bajo el control de la virtud.

En cuanto al tema del placer (i்oví), sabemos que Diógenes defendía la existencia de un placer superior que nacía del desprecio de los placeres aparentes, siempre que no se retrocediera ante el imperativo del ejercicio y del esfuerzo (SSR V B 291). De Antístenes, por su parte, se nos dice que «prefería enloquecer antes que sentir placer» (SSRV A 122). Se ha querido contraponer la teoría de Diógenes sobre el desprecio del placer a la de Antístenes que preconizaría el control del placer a través del autodominio-temperancia ('̇ $\gamma \kappa \rho \alpha ́ \tau \varepsilon 1 \alpha)$, que, al permitir soportar las necesidades (comida, bebida, sexo, sueño...), alcanzaría en su satisfacción «un placer digno de recuerdo». En cualquier caso, a partir de la lectura de otros testimonios sobre Antístenes, donde el placer auténtico se vincula con el esfuerzo, debemos reconocer la existencia de puntos de contacto con la visión de Diógenes. Y debemos reconocer igualmente que una parte de la tradición atribuye a Diógenes una actitud más positiva con respecto al placer, y que también en el caso de Antístenes hay otra parte de la tradición que lo presenta con una actitud más netamente rigorista, donde, sin embargo, el filósofo no se alza contra el placer sino contra el placer cuya falta de mesura produce sufrimiento ${ }^{45}$.

En cuanto a la religión, parece que las ideas de Antístenes estaban todavía lejos de lo que sería la disposición de los cínicos posteriores al respecto. En efecto, al parecer sería el único de los cínicos al que podría suponérsele el valor de la piedad. De todas formas, hay que reconocer que, por el intermedio de la oposición

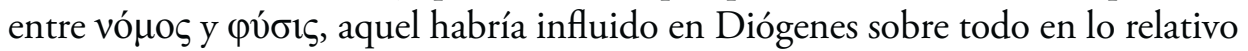
a la crítica de las tradiciones religiosas y supersticiones. Por su parte, Diógenes habría adoptado una actitud agnóstica (más allá del puro ateísmo): la existencia de la divinidad no le concerniría ni le interesaría en modo alguno (el cínico utiliza a los dioses sólo como un modo de compararse a su legendaria vida fácil, del mismo modo que recurre a los animales, moviéndose así en un plano intermedio entre ambos, que sería el plano correspondiente al hombre de verdad); en cualquier caso, su ideal de felicidad basado en la libertad real, la impasibilidad y la autosuficiencia sería contrario a la idea de religión de sus contemporáneos, y de ahí que la combatiera. Los cínicos posteriores habrían permanecido más bien fieles a este espíritu de Diógenes en lo relativo a la religión ${ }^{46}$.

\footnotetext{
${ }^{45}$ Remito para todo ello a Brancacci 1993.

46 Sobre los cínicos y la religión, $c f$. Goulet-Cazé 1993a.
} 
La imagen de este cinismo primero estaría incompleta sin mencionar también algunos cínicos ya estrictamente de época helenística, donde la crisis de las instituciones y de las creencias antiguas acabó en el colapso radical que transformó la realidad del individuo en un entorno especialmente sacudido por el azar. Una figura relevante entonces fue Menipo de Gádara, de finales del s. IV y mediados del III. Esclavo fenicio al servicio de un tal Batón en la región del Ponto, obtuvo pronto la libertad, practicando la mendicidad o la usura, según Diógenes Laercio (VI 99). Si bien tradicionalmente se ha interpretado como discípulo de Crates, debió de serlo de Metrocles ${ }^{47}$. Aunque no se nos ha conservado nada de él, destaca como inventor del género que se conoce desde el Renacimiento como «sátira menipea», mezcla de prosa y verso donde la crítica de los vicios humanos se realiza con un estilo que es una aguda mezcla también de seriedad y de comicidad (según la tradición propia de la poesía yámbica y de la comedia), que explica que Estrabón XVI 2, 29 lo califica de serio-cómico ( $\sigma \pi 0 v \delta 0 \gamma \varepsilon \dot{\lambda} \mathrm{oto}_{\text {) }}$. Sus ataques, según este peculiar estilo, debieron de dirigirse sobre todo contra epicúreos y estoicos, y su influencia en la literatura posterior fue enorme, tanto en la Antigüedad (citemos por ejemplo a Varrón o Luciano) como en el Renacimiento.

Del cinismo helenístico, contemporáneo de Menipo, hay que citar también a Bion de Borístenes (en Escitia, junto al Mar Negro), hijo de un liberto y de una prostituta, que se acercó a la filosofía cínica (quizá de nuevo por influencia de Crates, el cínico más relevante a principios del s. III a.C.) con el bagaje, sin embargo, de otras múltiples experiencias filosóficas (platonismo, hedonismo, aristotelismo) que denotan un carácter abiertamente ecléctico ${ }^{48}$. $\mathrm{Al}$ parecer, su actividad fue la de un filósofo itinerante con ciertos rasgos de tipo cínico (como la asunción del tabardo y la alforja), pero mezclados con otros contrarios en principio al cinismo, como el hecho de recibir dinero por sus lecciones, como los antiguos sofistas. Por los testimonios que nos han llegado en la biografía de Diógenes Laercio (IV 46-58), debió de conducirse como un maestro extravagante e histriónico, con un comportamiento marcado por claros rasgos cínicos como la impudencia o la irreverencia hacia los dioses, pero con otros que ponían de manifiesto su personalidad multiforme y versátil (muy afín sin duda de nuevo a los antiguos sofistas), y de una fortaleza más que dudosa. Se nos dice por ejemplo que en el momento en que le llegaba la muerte (en Calcis, en la isla de Eubea) su ateísmo flaqueó hasta el punto de que aceptó llevar amuletos y se arrepintió

${ }^{47}$ Es la interpretación acertada de Goulet-Cazé 1986b.

${ }^{48}$ Cf. Kindstrand 1976, pp. 56-78. 
de sus ataques a la divinidad, y que, encontrándose abandonado y solo, acabó aceptando los favores del monarca macedonio de entonces, el epígono Antígono Gonatas.

En esto acabó sin duda siguiendo los preceptos de su paso por la escuela hedonista. Se ha querido ver en el cinismo de Bion una orientación alejada del rigorismo de los primeros cínicos, más moderada y hasta hedonista. En mi opinión, extrapolar estas consideraciones hasta el punto de establecer en tales términos de mayor o menor rigorismo una distinción o evolución en la historia del cinismo no deja de ser problemático, entre otras cosas porque en los propios primeros maestros tenemos también testimonios de claras actitudes hedonistas, eso sí basadas en un hedonismo reacuñado, donde el desprecio del placer es visto como el mayor de los placeres. Lo que sí es verosímil, siempre teniendo en cuenta la personalidad de cada filósofo en cada momento, es que en el siglo III a.C. (con la crisis de la religión tradicional y la omnipresencia de la idea de la Fortuna) debió de tener mayor predicamento la postura de la acomodación del sabio a las contingencias de la vida. Y de este posicionamiento filosófico nos dan buen testimonio los fragmentos conservados de las prédicas de Teles, quien, como el propio Bion (sin duda algunos años mayor), recurría en sus lecciones morales a la metáfora del hombre sabio como un actor que debe saber representar igualmente bien cualquier papel que la fortuna le asigne, ya sea el de rey o el de mendigo ${ }^{49}$.

Por lo demás, desde el punto de vista literario se ha enfatizado también el papel de Bion, junto con Menipo, en el establecimiento de la sátira cínica dentro de la vieja tradición del estilo serio-cómico. Recordemos al respecto que, según Diógenes Laercio, Eratóstenes lo presentó como el primero que revistió la filosofía con un "manto florido", refiriéndose sin duda a la vestimenta de las cortesanas, con lo que daba a entender que Bion había en cierto modo prostituido la filosofía haciéndola objeto de ese tratamiento vulgar, y sabemos también por otras fuentes que Eratóstenes, como Teofrasto antes, juzgaba ese estilo indigno de vehicular un mensaje filosófico, aunque no sin reconocer un valor oculto en los discursos de apariencia vulgar de Bion ${ }^{50}$.

\footnotetext{
${ }^{49}$ Cf. Fuentes González 1988, 148-166, Id. 2009, 151-153. Para la discusión en torno a la cuestión de si puede establecerse una doble rama en la historia del cinismo basada en la oposición cinismo rigorista/moderado y para una exposición convincente de los argumentos en contra de dicha hipótesis remito asimismo a Goulet-Cazé 2014, 56-65.

${ }^{50}$ Cf. Diógenes Laercio IV 52 = Bion, test. 11 Kindstrand; Demetrio Lacón, p. 75 De Falco = test. 3 Kindstrand; Estrabón I 2, 2 = Bion, test. 12 Kindstrand.
} 


\section{A modo de conclusión}

Hombres y mujeres (por recordar al menos el ejemplo notable de Hiparquia) de un tiempo de crisis, los primeros cínicos representaron un verdadero desafío para sus contemporáneos. Radicalmente opuestos a los modos de vida y de pensamiento imperantes, lejos de apartarse en un retiro indiferente, se mantuvieron insertos en el seno de la sociedad de su tiempo. Lo hicieron ante todo como el mejor modo de realizar el cinismo por ellos descubierto (por el ejemplo de otros, hombres o animales, o por su propia peripecia personal), a través del desaprendizaje (o falsificación) de todo aquello que está en el origen de la esclavitud real del individuo y de su desdicha, y como el mejor modo de confirmar las claves de la verdadera libertad y felicidad.

En ese contexto hostil es donde, como atletas y soldados de la filosofía, se entrenan y combaten cotidianamente los cínicos, en los espacios públicos, con el objetivo de convertirse en seres felices, autosuficientes y libres, desafiando con su actitud a aquellos con los que se tropiezan, distinguiéndose de ellos como los verdaderos especímenes del hombre. De paso pueden quizá de este modo servir también de ejemplo a algunos de sus contemporáneos, aunque esa no sea propiamente su misión, sino la de vivir cada uno su vida como seres autónomos y autosuficientes, todo lo autónomos y autosuficientes que está en la naturaleza humana, con sólo saber recuperar y mantener su esencia (a través del entrenamiento cínico), por más que ello suponga una tentación constante ante los múltiples enemigos bajo cuyo poder se encuentran sometidos el resto de los mal llamados hombres.

De este modo, el cínico se erige ante sus contemporáneos como una fortaleza, parapetado en los tan firmes como sencillos principios que le dictan las leyes de la naturaleza humana. Con la pobreza como la mejor compañera de viaje, para perderse lo menos posible en las ataduras de los mal llamados bienes materiales, y con el empeño asimismo de la insensibilidad, para igualmente mantenerse al margen de los lazos de dependencia con respecto a otros hombres y mujeres, el cínico es un atleta de la virtud, y como tal cultiva la fuerza del espíritu como su bien más preciado.

Fueron los cínicos individuos y existencias desafiantes en el siglo IV a.C., el gran siglo de la filosofía, y en su escenario por excelencia, la ciudad de Atenas, pero itinerantes también en otras muchas ciudades, en su condición de seres libres de toda atadura a una patria o ciudad concreta, ciudadanos en este sentido 
del mundo. Y ahí sin duda cumplieron una función singular, a través de su palabra y sobre todo de su acción, firmes, valientes y desafiantes ante la sociedad y la cultura de su tiempo, por más que sin duda su radical desafío, como era de esperar, no alcanzara a tener apenas predicamento entre sus contemporáneos y por más que de esa voz segura y firme nos hayan llegado en la tradición sólo pobres ecos lejanos y distorsionados. Y como críticos y satíricos de la sociedad y de la cultura de su tiempo debieron de seguir desempeñando un papel singular en el mundo helenístico, como testigos y delatores de todo tipo de incoherencias y vicios, de esos mismos vicios e incoherencias de los que tampoco ellos mismos estaban libres sin más, porque el cinismo verdadero es una filosofía que requiere un entrenamiento y un esfuerzo constantes, se hace en un combate día a día y necesita por tanto de espíritus extraordinarios y heroicos. Antístenes, Diógenes, Crates, Metrocles o Hiparquia representaron sin duda esa generación más decididamente heroica del cinismo antiguo. Poco después otros, como Menipo o Bion, prosiguieron el desafío cínico, aunque quizá en su caso se tradujo más en críticas y sátiras literarias que en un compromiso real de vida. Andando el tiempo, y sobre todo en época imperial, proliferará también la figura del falso cínico vulgar, que ocultaba los vicios del parásito y del charlatán bajo la apariencia y la indumentaria del filósofo ${ }^{51}$.

\footnotetext{
${ }^{51}$ Sobre la época imperial (que se sale del marco del presente trabajo), remito en particular a Goulet-Cazé 1990 y más recientemente a Ead. 2014, 51-97, que llama la atención sobre la extraordinaria complejidad y diversidad que presenta en esa época el panorama del cinismo, como reflejo de concepciones diferentes de una filosofía que no se reducía desde luego entonces en modo alguno a esa figura del cínico vulgar, parásito y charlatán. Fue esta sin duda, eso sí, la que mejor se prestaba a las encendidas críticas de los contemporáneos (por ejemplo, las de Luciano, en la tradición justamente de la sátira menipea).
} 


\section{Bibliografía}

BADIAN, E. (1958). «Alexander the Great and the unity of mankind», Historia 7, 425444.

Baldry, H. C. (1965). The unity of mankind in Greek thought, Cambridge: Cambridge University Press.

Billerbeck, M. (1978). Epiktet: Vom Kynismus, hrsg. und übers. mit einem Kommentar, Leiden: Bill.

_- (1982). «La réception du cynisme à Rome», L'Antiquité Classique 51, 151-173.

— (1993). «Le cynisme idéalisé d'Épictète à Julien», en Goulet-Cazé \& Goulet (eds.) 1993, 319-338 (la trad. esp. de este artículo en Branham \& Goulet-Cazé [eds.] 2000, 270-290, enmascara sus planteamientos originales, al traducirse como «ideal cínico» lo que debería haberse traducido como "cinismo idealizado»).

Bodei Giglioni, G. (1984). «Una leggenda sulle origini dell'ellenismo: Alessandro e i cinici», en B. Virgilio (ed.), Studi ellenistici, Pisa: Giardini, 51-73.

BöHr, Ch., (2003). Philosophie für die Welt: die Popularphilosophie der deutschen Spätaufklärung im Zeitalter Kants, Stuttgart: Frommann-Holzboog.

Bouffartigue, J., (1993). «Le cynisme dans le cursus philosophique au Iv siècle: le témoignage de l'Empereur Julien», en Goulet-Cazé \& Goulet (eds.) 1993, 339358.

Brancacci, A. (1977). "Le orazioni diogeniane di Dione Crisostomo», en G. Giannantoni (ed.), Scuole socratiche minori e filosofia ellenistica, Bologna: Il Mulino, 141171.

(1980). «Tradizione cinica e problemi di datazione nelle orazioni diogeniane di Dione di Prusa», Elenchos 1, 92-122.

— (1993). «Érotique et théorie du plaisir chez Antisthène», en Goulet-Cazé \& Goulet (eds.) 1993, 35-55.

— (2005). Antisthène: le discours propre, trad. del orig. ital. (1990), Paris: Vrin.

Branham, R. B. (1993). "Diogenes' rhetoric and the invention of cynicism», en Goulet-Cazé \& Goulet (eds.) 1993, 445-473.

- \& Goulet-Cazé, M.-O. (eds.) (2000). Los cínicos: el movimiento cínico en la Antigüedad y su legado, trad. esp. del orig. ing. (1996), Barcelona: Seix Barral.

Clément, M. (2005). Le cynisme à la Renaissance d'Érasme à Montaigne, suivi de Les Epistres de Diogenes (1546), Genève: Droz.

Cuesta, J. A. (2006). Filosofía cínica y crítica ecosocial, Barcelona: Ediciones del Serbal. 
- (2011). Ecocinismos: la crisis ecológica desde la perspectiva de la filosofía cínica, Barcelona: Biblioteca Buridán.

DambsкA, I. (1973). «Cynicy: hippisi starozytnego swiata», Filomata 267, 339-348.

Desmond, W. D. (2005). The Greek praise of poverty: origins of ancient cynicism, Notre Dame: University of Notre Dame Press.

- (2008). Cynics, Berkeley (CA): University of California Press.

Dorandi, T. (1982). «Filodemo. Gli Stoici (PHerc. 155 e 399)», Cronache Ercolanesi $12,91-133$.

_ (1993). «La Politeia de Diogène de Sinope et quelques remarques sur sa pensée politique», en Goulet-Cazé \& Goulet (eds.) 1993, 57-68.

Fornet-Betancourt, R. (2002). Modelle befreiender Theorie in der europäischen Philosophiegeschichte: ein Lehrbuch, Frankfurt am Main: IKO-Verlag für Interkulturelle Kommunikation.

Fuentes González, P. P. (1998). Les diatribes de Télès: introduction, texte revu et commentaire des fragments, avec en appendice une traduction espagnole, Paris: Vrin.

(2000). «Ératosthène de Cyrène», en R. Goulet (ed.), Dictionnaire des philosophes Antiques, Paris: CNRS, III, 188-236.

- (2002). «El atajo filosófico de los cínicos antiguos hacia la felicidad», Cuadernos de Filologia Clásica: Estudios Griegos e Indoeuropeos 12, 203-251.

— (2003). «¿Necesitaban de un amigo los cínicos antiguos?», Bitarte 31, 51-72.

— (2009). «Le Démonax de Lucien entre réalité et fiction », Prometheus 35, 139-158.

_ (2011). "Cyniques et autres 'philosophes populaires' chez Stobée», en G. Reydams-Schils (ed.), Thinking through excerpts: studies on Stobaeus, Turnhout: Brepols, $387-440$.

— (2013). «En defensa del encuentro entre dos Perros, Antístenes y Diógenes: historia de una tensa amistad", Cuadernos de Filología Clásica: Estudios Griegos e Indoeuropeos 23, 225-267 (reprod. con algunas modificaciones en V. Suvák [ed.], Antisthenica Cynica Socratica, Praha: Oikoumene, 2014, 11-71).

— (2015). «La reacuñación cínica de la familia en Crates de Tebas», en S. López Quero \& J. Ma Maestre Maestre (eds.), Studia Angelo Vrbano Dicata, Alcañiz-Madrid: Instituto de Estudios Humanísticos - Federación Andaluza de Estudios Clásicos, 201-217.

Giannantoni, G. (1988). «Cinici e stoici su Alessandro Magno», en G. Casertano (ed.), I filosofi e il potere nella società e nella cultura antiche, Napoli: Guida, 75-87.

— (1990). Socratis et Socraticorum Reliquiae, 4 vol., Napoli, Bibliopolis (= SSR). 
GIL, L. (1980-1981). «El cinismo y la remodelación de los arquetipos culturales griegos", Revista de la Universidad Complutense 28, 43-78.

GoulEt, R. (2007). «La conservation et la transmission des textes philosophiques grecs», en C. D'Ancona (ed.), The Libraries of the Neoplatonists: Proceedings of the Meeting of the European Science Foundation Network 'Late Antiquity and Arabic Thought. Patterns in the Constitution of European Culture' Held in Strasbourg, March 12-14, 2004, Leiden: Brill, 29-61.

Goulet-Cazé, M.-O. (1986a). L'ascèse cynique: un commentaire de Diogène Laërce VI 70-71, Paris: Vrin $\left(2001^{2}\right)$.

(1986b). «Une liste de disciples de Cratès le Cynique en Diogène Laërce 6, 95», Hermes 114, 247-252.

(1990). «Le cynisme à l'époque impériale», en W. Haase (ed.), ANRW II 36, 4, Berlin/New York: de Gruyter, 2720-2833.

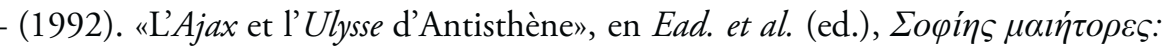
«chercheurs de sagesse»: hommage à Jean Pépin, Paris: Institut d'Études Augustiniennes, 5-36.

(1993a). «Les premiers cyniques et la religion», en Goulet-Cazé \& Goulet (eds.) 1993, 117-158.

(1993b). «Le cynisme est-il une philosophie?», en M. Dixsaut (ed.), Contre Platon, vol. I: L'antiplatonisme dévoilé, Paris: Vrin, 273-313.

— (2000). «¿Quién fue el primer Perro?», en Branham \& Goulet-Cazé (eds.) 2000, $532-534$.

_ (2003). Les Kynika du stö̈cisme, Stuttgart: Steiner.

(2010). «Les cyniques dans l'Antiquité, des intellectuels marginaux?», Museum Helveticum 67, 100-113.

_ (2014). Cynisme et christianisme dans l'Antiquité, Paris: Vrin.

— \& Goulet, R. (eds.) (1993). Le cynisme ancien et ses prolongements. Actes du Colloque international du CNRS (Paris, 22-25 juillet 1991), Paris: Presses Universitaires de France.

Gugliermina, I. (2006). Diogène Laërce et le cynisme, Villeneuve-d'Ascq: Presses Universitaires du Septentrion.

Heges, G. W. (1990). Introducción a la historia de la filosofia, Madrid: Aguilar.

Heinrich, K. (1988). «Gli antichi cinici e il cinismo del presente», en Parmenide e Giona: quattro studi sul rapporto tra filosofia e mitologia, trad. ital. del orig. alem. (1966, 1982), Napoli: Guida, 141-165. 
HöIstad, R. (1948). Cynic hero and cynic king. Studies in the cynic conception of man, Diss. Uppsala, Lund: Blom.

Husson, S. (2011). La République de Diogène: une cité en quête de la nature, Paris: Vrin.

IsNardi Parente, M. (1985-1986). «Filosofia postaristotelica o filosofia ellenistica: storia di un concetto storiografico", Annali dell'Istituto Italiano per gli Studi Storici 9, 165-193.

Kindstrand, J. F. (1976). Bion of Borysthenes: a collection of the fragments with introduction and commentary, Uppsala: Almqvist \& Wiksell.

López Cruces, J. L. (2010). «Une tragédie perdue: l'Héraclès de Diogène le Cynique», Les Études Classiques 78, 3-24.

_ (2015). «Diógenes, ciudad sin ley», en A. Pociña Pérez \& J. Ma García González (eds.), En Grecia y Roma, V: Hombres notables, Granada: Universidad de Granada, 177-194.

Martín García, J. A. (2008). Los filósofos cínicos y la literatura moral serioburlesca, texto corr. y revis. por C. Macías Villalobos, 2 vol., Tres Cantos: Akal.

Merlan, Ph. (1950). «Alexander the Great or Antiphon the Sophist?», Classical Philology 45, 161-166.

Miralles, C. (1970). «Los cínicos, una contracultura en el mundo antiguo», Estudios Clásicos 14, 347-377.

Navia, L. E. (1996). Classical cynicism: a critical study, Westport (Conn.)-London: Greenwood Press.

_ (1998). Diogenes of Sinope: the man in the tub, Westport (Conn.)-London: Greenwood Press.

- (2001). Antisthenes of Athens: setting the world aright, Westport (Conn.)-London: Greenwood Press.

Nienues-Pröbsting, H. (1979). Der Kynismus des Diogenes und der Begriff des Zynismus, München: Fink.

_ (1980). «Der "kurze Weg": Nietzsches "Cynismus"», Archiv für Begriffsgeschichte 24, 103-122.

_ (2000). «La recepción moderna del cinismo: Diógenes y la Ilustración», en Branham \& Goulet-Cazé (eds.) 2000, 430-474.

Onfray, M. (1990). Cynismes: portrait du philosophe en chien, Paris: Grasset.

Pons Olivares, D. (2009). «D.L. VI 93: Crates, ciudadano de Diógenes: una revisión del cosmopolitismo cínico», en J. F. González Castro et al. (eds.), Perfiles de Grecia y Roma: actas del XII Congreso Español de Estudios Clásicos, Valencia, 22 al 26 de octubre de 2007, Madrid: Sociedad Española de Estudios Clásicos, I, 575-582. 
Prince, S. (2006). "Socrates, Antisthenes and the cynics», en S. Ahbel-Rappe \& R. Kamtekar (eds.), A companion to Socrates, Oxford/Malden (Mass.): Blackwell, 75-92.

Ramírez Vidal, G. (1998). «Humanismo y cosmopolitismo en Antifonte», Habis 29, $37-50$.

Roca Ferrer, J. (1974). Kynikòs trópos: cinismo y subversión literaria en la Antigüedad, Barcelona: Universidad de Barcelona (Tesis 1973).

Runia, D. T. (1999). «What is doxography?», en Ph. J. van der Eijk (ed.), Ancient histories of medicine: essays in medical doxography and historiography in classical Antiquity, Leiden: Brill, 33-55.

Shmueli, E. (1970). «Modern hippies and ancient cynics: a comparison of philosophical and historical developments and its lessons», Journal of World History 12, 490514.

Sloterdijk, P. (1989). Crítica de la razón cínica, trad. esp. del orig. alemán (1983), pres. de F. Savater, 2 vol., Madrid: Taurus.

TARN, W. W. (1939). «Alexander, cynics and stoics», American Journal of Philology 60, 41-710.

Teodorsson, S.-T. (2007). «Atenas como ambiente del cinismo», en A. Bernabé \& I.

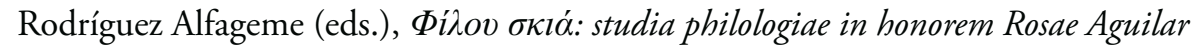
ab amicis et sodalibus dicata, Madrid: Universidad Complutense, 49-58.

Windt, Th. O. (1972). «The diatribe: last resort for protest», The Quarterly Journal of Speech 58, 1-14.

Xenakis, J. (1973). «Hippies and cynics», Inquiry 16, 1-15.

Recibido: 6/02/2016

Aceptado: 4/11/2016

Este trabajo se encuentra bajo una licencia de Creative Commons Reconocimiento-NoComercial-SinObraDerivada 4.0 
